\title{
Adult Spinal Cord Stem Cells Generate Neurons after Transplantation in the Adult Dentate Gyrus
}

\author{
Lamya S. Shihabuddin, Philip J. Horner, Jasodhara Ray, and Fred H. Gage \\ The Salk Institute, Laboratory of Genetics, La Jolla, California 92037
}

\begin{abstract}
The adult rat spinal cord contains cells that can proliferate and differentiate into astrocytes and oligodendroglia in situ. Using clonal and subclonal analyses we demonstrate that, in contrast to progenitors isolated from the adult mouse spinal cord with a combination of growth factors, progenitors isolated from the adult rat spinal cord using basic fibroblast growth factor alone display stem cell properties as defined by their multipotentiality and self-renewal. Clonal cultures derived from single founder cells generate neurons, astrocytes, and oligodendrocytes, confirming the multipotent nature of the parent cell. Subcloning analysis showed that after serial passaging, recloning, and expansion, these cells retained multipotentiality, indicating that they are self-renewing. Transplantation of an in vitro-expanded clonal
\end{abstract}

population of cells into the adult rat spinal cord resulted in their differentiation into glial cells only. However, after heterotopic transplantation into the hippocampus, transplanted cells that integrated in the granular cell layer differentiated into cells characteristic of this region, whereas engraftment into other hippocampal regions resulted in the differentiation of cells with astroglial and oligodendroglial phenotypes. The data indicate that clonally expanded, multipotent adult progenitor cells from a non-neurogenic region are not lineage-restricted to their developmental origin but can generate region-specific neurons in vivo when exposed to the appropriate environmental cues.

Key words: spinal cord; stem cells; FGF; transplantation; neuroplasticity; adult
Most neurogenesis in the mammalian CNS is believed to end in the period just after birth (Nornes and Das, 1974; Altman and Bayer, 1984). However, neurogenesis continues in different regions of the brain of various adult mammalian species (Kaplan and Hinds, 1980; Bayer et al., 1982; Lois and Alvarez-Buylla, 1993, 1994; Luskin, 1993). The spinal cord, like most structures of the mammalian brain, belongs to the class of nonrenewable epithelium (Rakic, 1985). However, a small number of cells that line the central canal (Adrian and Walker, 1962; Johansson et al., 1999) remain mitotic. We have demonstrated recently that the adult rat spinal cord contains large numbers of dividing cells in vivo that give rise to glia but not neurons (Horner et al., 2000).

Multipotent stem cells that respond to epidermal growth factor (EGF) or basic fibroblast growth factor (FGF-2) have been isolated from both neurogenic (Morshead et al., 1994; Palmer et al., 1997) and non-neurogenic regions (Weiss et al., 1996) of the adult mammalian CNS (Temple and Alvarez-Buylla, 1999). Recent studies indicate that embryonic day 14 mouse striatum or adult subventricular zone (SVZ) contains multipotent stem-like cells that are controlled by FGF-2 or EGF in a regulatable manner (Ciccolini and Svendsen, 1998; Gritti et al., 1999). However, this is not true of adult CNS stem cells from all regions, because a combination of EGF and FGF-2 was necessary to isolate stem cells from the adult mouse spinal cord (Weiss et al., 1996), whereas FGF-2 alone was sufficient to isolate neural progenitors from the adult rat spinal cord (Shihabuddin et al., 1997). This finding raises several questions, such as the following: do FGF-2-responsive cultures from the adult rat spinal cord contain progenitor or stem cells, are the cells isolated from the spinal cord similar to those isolated from neuro-

Received Aug. 2, 2000; revised Sept. 11, 2000; accepted Sept. 15, 2000.

This work was supported by grants from the Paralyzed Veterans of America Spinal Cord Research Foundation, the Christopher Reeve Paralysis Foundation, The Hollfelder Foundation, and the Lookout Fund and by the National Institute of Neurological Diseases and Stroke Grant NO1-NS-6-2348. This publication was also made possible by grants from the National Institute on Aging and the National Institutes of Health. We thank M. Gage and Drs. Naomi Kleitman and Theo Palmer for helpful critique of this manuscript.

Correspondence should be addressed to Dr. Fred H. Gage, The Salk Institute, Laboratory of Genetics, 10010 North Torrey Pines Road, La Jolla, CA 92037. E-mail: fgage@salk.edu.

Copyright (C) 2000 Society for Neuroscience $0270-6474 / 00 / 208727-09 \$ 15.00 / 0$ genic sites such as the hippocampus, and is their developmental fate influenced by environmental factors?

Transplantation studies have been used to demonstrate whether in vitro-expanded cells can faithfully exhibit migration and differentiation of cells present in vivo (Brustle et al., 1997, 1998; Flax et al., 1998). Hippocampal-derived FGF-2-responsive progenitors transplanted into different regions of the adult rat brain differentiate into region-specific neurons only in neurogenic sites (Suhonen et al., 1996). Transplantation of cultured stem-like cells into different CNS microenvironments is thus an excellent way to determine the plasticity of cells derived from neurogenic and non-neurogenic regions.

In the present study we demonstrate, via subcloning analysis, that FGF-2-responsive adult spinal cord-derived cells are self-renewing and multipotent and thus possess stem cell characteristics. Furthermore, using transplantation studies, we show that the progeny of cloned, FGF-responsive stem cells exhibit a broad developmental plasticity and differentiate into neurons in a region-specific manner after transplantation into the adult rat CNS.

\section{MATERIALS AND METHODS}

Isolation and culturing of adult progenitors. Isolation of the FGF-2responsive progenitor cells from the adult rat spinal cord has been described previously (Shihabuddin et al., 1997). Adult rat spinal cord (3 months old) was microdissected by region (cervical, thoracic, lumbar, and sacral), tissue was mechanically and enzymatically dissociated with papain-protease-DNase solution, and then digestion was stopped. The dissociated cells were grown on polyornithine and laminin-coated plates in N2 medium containing FGF-2 (20 ng/ml). The cells grew as attached cultures. Cultures were passaged by trypsinizing, and rapidly proliferating cells that could be passaged, frozen, thawed, and recultured were isolated.

Cloning and subcloning. Adult spinal cord progenitors were treated with a replication-defective retroviral vector expressing the LacZ gene that codes for $\beta$-galactosidase from long terminal repeat (LTR) and neomycinresistant gene (neo) from Rous sarcoma virus in LTR (LZRNL), prepared using standard methods (Miller and Rosman, 1989). Cells were exposed to medium containing up to $10 \%$ virus stocks prepared from PA317 packaging cells for $18-24 \mathrm{hr}$ and then were replated at $\sim 1 \%$ of their initial density in the presence of $100 \mu \mathrm{g} / \mathrm{ml} \mathrm{G} 418$. Individual clusters of proliferative cells were transferred to 96-well plates ( 1 clone/well) using glass pipettes. Clones were expanded, and the clonality of cells was established by determining the integration site of the retroviral genome within the cellular genome. For subcloning, individual primary clones were dissociated to a single-cell suspension and replated at low clonal density $\left(10^{3}\right.$ cells $/ \mathrm{ml}$ ). Single clusters of dividing cells, secondary clones, were again transferred to 96 -well plates ( 1 clone/well) using glass pipettes. For South- 
ern blot analysis, genomic DNA was harvested from cultures and then digested using restriction enzymes (Bam HI and Pst I). Digested DNA was resolved on agarose gels and transferred to nylon membranes where vector-specific bands were detected by hybridization to a ${ }^{32} \mathrm{P}$-labeled neomycin resistance gene (neo) transgene probe and visualized using a phosphoimager (Palmer et al., 1997).

In vitro immunocytochemistry and quantitative analyses. For differentiation experiments, cells were plated, at a density of $\sim 10^{5}$ cells $/ \mathrm{cm}^{2}$ (highdensity cultures), onto polyornithine and laminin-coated glass chamber slides (Nunc, Naperville, IL). The cells were incubated for $24 \mathrm{hr}$ in N2 medium containing $20 \mathrm{ng} / \mathrm{ml}$ FGF-2, and then the medium was replaced by $\mathrm{N} 2$ medium containing $0.5 \%$ fetal bovine serum (FBS) or both $0.5 \%$ FBS and $0.5 \mu \mathrm{M}$ all-trans-retinoic acid (RA; Sigma, St. Louis, MO). The medium was replaced every $2 \mathrm{~d}$. After differentiation for $6 \mathrm{~d}$, cultures were fixed and stained with one of the following antibodies: mouse anti-nestin (1:1000; PharMingen, San Diego, CA), mouse anti- $\beta$-tubulin (1:1000; Sig$\mathrm{ma})$, rabbit anti-high-molecular weight neurofilament (anti-NF-200; 1:600; Chemicon, Temecula, CA), rabbit anti-glial fibrillary acidic protein (antiGFAP; 1:2000; Dako, Carpinteria, CA), and mouse anti-Rip, a monoclonal antibody that stains oligodendrocytes and their processes (1:100). The primary antibodies were detected with fluorescent secondary antibodies. Labeled cells were visualized using confocal scanning laser microscopy. For each marker, 500-1000 cells were sampled systematically from standardized fields at $40 \times$ magnification and then examined and scored for immunoreactivity. Each experiment was repeated three times. Differences in the percentage of cells expressing each antigenic marker between cultures grown under various conditions were evaluated statistically using multivariate ANOVA and post hoc Student's $t$ test.

Labeling methods and preparing cells for transplantation. To enable the detection of cells in vivo, expanded cultures of a cervical clone were labeled with bromodeoxyuridine (BrdU), which was added to the culture medium at $0.5 \mu \mathrm{M}$ concentration $48 \mathrm{hr}$ before the preparation of cells for transplantation. When 60-70\% confluent, cultures were trypsinized, and cells were washed with $0.1 \mathrm{M}$ PBS, collected by centrifugation at $2500 \mathrm{rpm}$ for 3 min, and resuspended in $1 \mathrm{ml}$ of DMEM-F12 medium. To check the cell viability, an aliquot of the suspension was removed and mixed with trypan blue. The cell suspension was centrifuged a second time and resuspended in a smaller volume of $0.1 \mathrm{M}$ PBS to give the equivalent of $100,000 \mathrm{cells} / \mu \mathrm{l}$.

Adult transplantation, immunostaining, and quantitative analysis. Expanded cultures of a cervical clone $(100,000-150,000$ cells in $1-1.5 \mu \mathrm{l})$ labeled with BrdU were stereotaxically injected unilaterally into the spinal cord at T7-T9 (mediolateral, $+0.5 \mathrm{~mm}$; dorsoventral, $1 \mathrm{~mm}$ from dura) and the hippocampus (anteroposterior, $-4.2 \mathrm{~mm}$; mediolateral, $+3.0 \mathrm{~mm}$ dorsoventral, $-3.0 \mathrm{~mm}$ from the dura with the nose bar at $5 \mathrm{~mm}$ up) of adult female (3-month-old) Fischer 344 rats. At 2 weeks $(n=4)$ and 6 weeks $(n=8)$ after transplantation, animals were perfused, the transplant site in the spinal cords was blocked and sectioned $(20 \mu \mathrm{m}$ horizontal sections), and the brains were sectioned (40 $\mu \mathrm{m}$ coronal sections). For immunofluorescence staining, sections (every 6th or 12th section) were pretreated for BrdU detection (Gage et al., 1995) and stained with antibodies for the neuronal markers mouse anti-NeuN (1:20; from R. Mullen) and rabbit anti-calbindin (1:1000; S. Want), for the glial progenitor marker rabbit anti-NG2 (1:500; Chemicon), for the astroglial marker rabbit antiGFAP (1:2000; Dako), and for the oligodendroglial markers mouse antiRip (1:20; hybridoma bank) and mouse anti-adenomatous polyposis coli (anti-APC; 1:20; Oncogene). The secondary antibodies used in triple labeling were donkey anti-species FITC, cyanin 3 (cy3) or cyanin 5 (cy5) (1:250; Jackson ImmunoResearch, West Grove, PA). Sections were imaged using a Bio-Rad (Hercules, CA) MRC1000 confocal microscope. To examine the distribution of transplanted cells, semiserial sections (every 6th or 12 th section) containing the hippocampus or transplant site in the spinal cord were stained immunohistochemically for BrdU, and the number of BrdU-positive cells was quantified using a modified stereological procedure (Gage et al., 1995). Briefly, the total transplant volume was estimated using the Cavalieri procedure. The number of BrdU-positive cells in each section was sampled in a systematic, uniform, random manner using a stereological grid and the optical dissector procedure for sampling within the tissue. The results of this procedure provided a numerical density (cells per unit volume). The data from the optical dissector and Cavalieri procedure were combined to yield an estimate of the number of BrdUpositive cells in this series of sections. Quantitative data were compiled and analyzed statistically. To determine the frequency at which BrdU-positive cells demonstrated a neuronal or glial phenotype, BrdU-immunoreactive transplanted cells (100-200 cells) in each region were examined for colocalization with either neuronal or glial markers in triple-immunostained sections. The number of cells for each phenotype was expressed as a percentage of the BrdU-positive cells examined. To determine whether transplanted cells were dividing after transplantation, sections were double immunostained for BrdU and Ki-67 polyclonal (1:1000; Novocastra).

For control transplants, an equivalent number of BrdU-labeled fibroblasts or freeze-thawed BrdU-labeled expanded cultures of a cervical clone (cells suspended in PBS at $10^{5} / \mu$ l were freeze-thawed three times at $-70^{\circ} \mathrm{C}$, and the viability of cells was checked by trypan blue exclusion before injection) were stereotaxically injected into the adult rat hippocampus at the same coordinates described above.

Reverse transcriptase-PCR. Total RNA was isolated from transplant site regions of the spinal cord and hippocampus using RNAzol B (Tel-Test,
Inc.). cDNA was synthesized using $2 \mu \mathrm{g}$ of total RNA in a $20 \mu \mathrm{l}$ reaction. The Superscript Preamplification system (Life Technologies, Gaithersburg, MD) was used, and the Life Technologies protocol was followed. For the first PCR reaction, aliquots of $\mathrm{CDNA}$, equivalent to $1 / 40$ of the above reaction, were used in a $50 \mu \mathrm{l}$ reaction. For the nested PCR reaction, a $2 \mu \mathrm{l}$ aliquot of the first reaction was used for amplification. Two sets of primers were used for the neomycin gene; the external primers for the first PCR (nucleotides $158-757,599 \mathrm{bp}$ product) were 5'-TGTCCGGTGCCCTGAA TGAAC-3' and 5'-AAGGCGATAGAAGGCGATGCG-3', and internal primers for the nested PCR (nucleotides 271-710, 439 nucleotides) were 5'-TGGCTGCTATTGGGCGAAGTG-3' and 5'-AAGGCGATAGAAG GCGATGCG-3'. The first PCR was run for 30 cycles, and the nested PCR was run for 28 cycles; a 10 min incubation at $72^{\circ} \mathrm{C}$ was added at the end to ensure complete extension.

\section{RESULTS}

\section{FGF-responsive cells from the adult rat spinal cord are multipotent and self-renewing}

The isolation and the in vitro characteristics of FGF-2 progenitor cells isolated from different regions (cervical, thoracic, lumbar, and sacral) of the adult rat spinal cord have been described previously (Shihabuddin et al., 1997). Briefly, in the presence of FGF-2 in defined medium, all areas of the spinal cord generated rapidly proliferating cells. A percentage of cells in all cultures differentiate into cells with antigenic properties of neuronal, astroglial, and oligodendroglial lineages; however, the majority of cells from all regions were immunoreactive for the neuroepithelial cell marker nestin. A defining characteristic of stem cells is their ability to self-renew (Hall and Watt, 1989). To demonstrate self-renewal and hence the stem cell-like properties of cultured adult spinal cord progenitor populations, we determined whether clonal populations of FGF-dependent cells produced multipotent progeny after subcloning. Clonal cultures were generated by infecting low-passage cultures (passage 6) with a replication-defective retroviral vector carrying the marker gene LacZ and a selectable marker, neo, followed by plating cells at limiting dilution under selection for the expression of the neo gene. Individual clusters of proliferating cells that are well separated from their neighbors and thought to have originated from individually identified cells were transferred into separate wells of a 96-well plate by the use of glass pipettes and expanded further. Single copies of the retrovirus integrate at random within the cellular genome, and the relative position of the integration site within the cellular genome provides a unique genetic marker of all cells derived from the original infected cell. The clonality of cells from each clone was confirmed by Southern blot analysis of DNA digested with two different restriction enzymes to exclude the probability of small levels of clonal contamination. Only clones displaying a single integration site were included in subsequent studies. Secondary clones were then generated by dissociation of primary clones into a single-cell suspension and followed by a repetition of the cloning procedure (Fig. 1). Cells were used between passages 1 and 12 after cloning (up to $\sim 25$ passages from initial isolation).

More than 50 clones were harvested from each region. Approximately $25 \%$ of the picked clones per region continuously proliferate to establish primary clones. The small number of clones that were isolated and analyzed does not provide an indication of the frequency at which proliferative clones were isolated from the parent culture. To determine what proportion of the isolated clones were multipotent, a randomly chosen subset of primary clones was subcloned, and the progeny of both the proliferative secondary clones and the corresponding primary clones $(n=5)$ were assessed for the presence of lineage-specific markers characteristic of neurons, astrocytes, and oligodendrocytes. All clones evaluated to date have generated all three cell types, indicating that each was derived from a multipotent progenitor. For example, Southern blot analyses of BamHI- and PstI-digested DNA from a secondary clone (Fig. $2 B$ ) from the cervical region of the spinal cord showed a single integration site of the viral genome. In PstI-digested DNA, two bands are detected because the PstI restriction site lies within the region detected by a neo probe, as shown in the retroviral construct map (Fig. 2A). These data indicate that cells were derived from a 


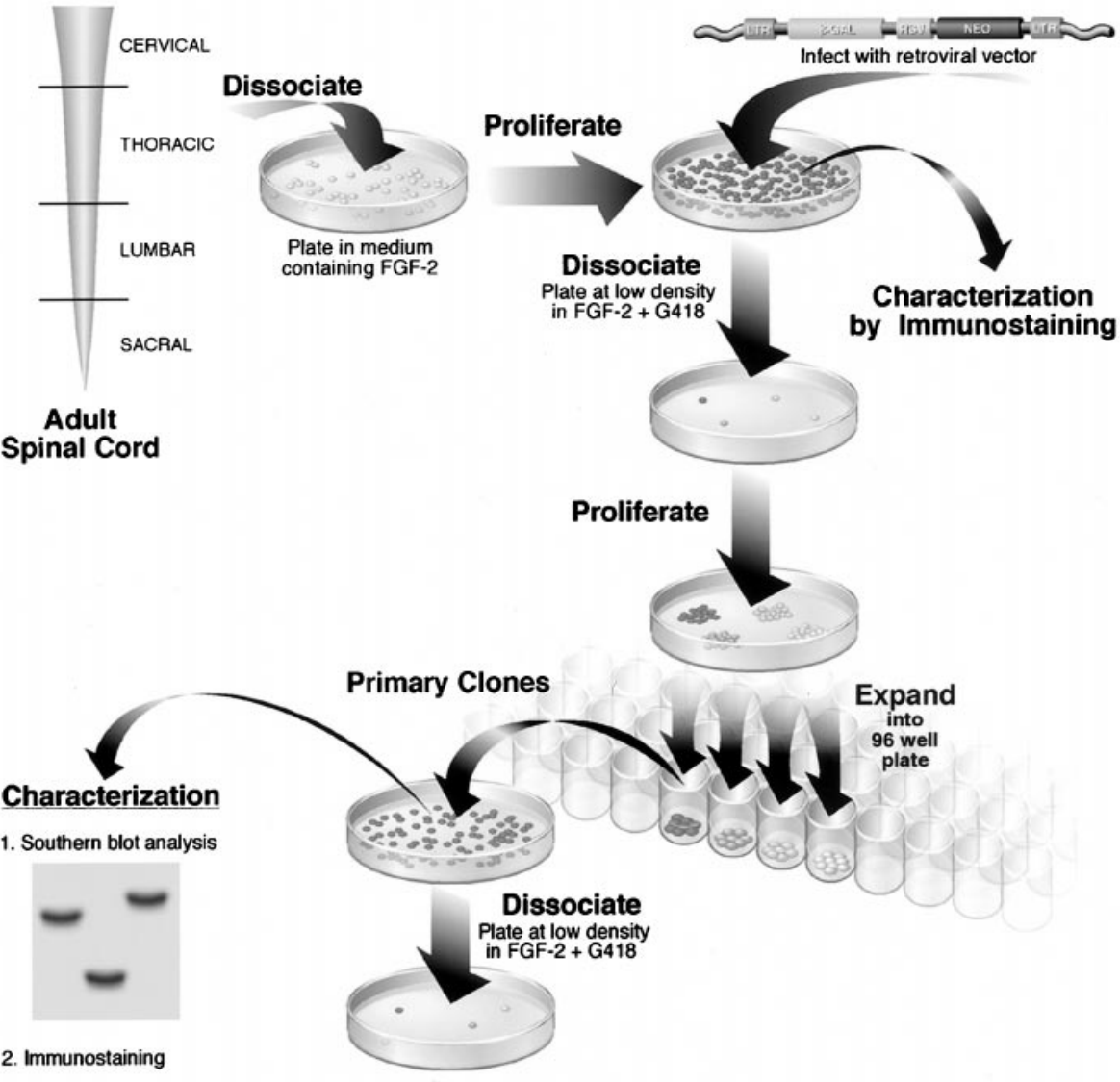

2. Immunostaining

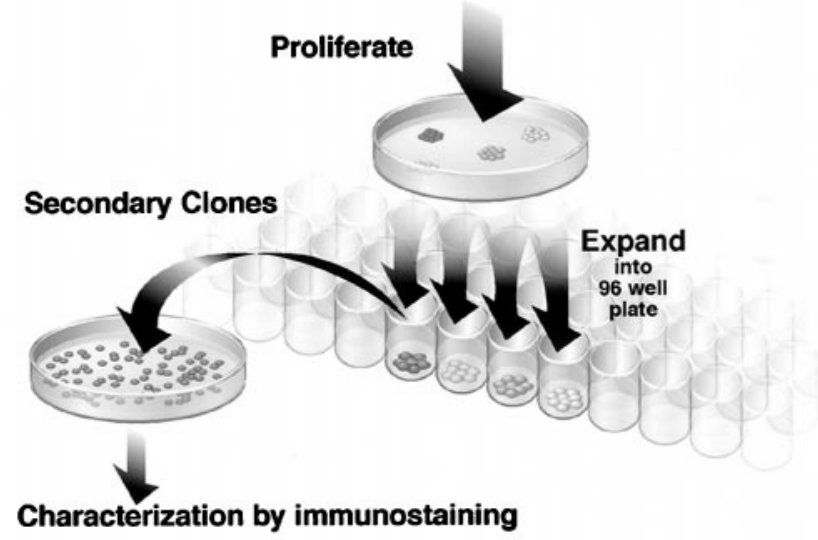

Figure 1. Schematic representation of the method used to assess multipotency and selfrenewal of FGF-2-responsive, adult-derived spinal cord cells. For cloning, progenitor cells in vitro were labeled with a retroviral marker, and Southern blot analysis was used to show that a cluster of proliferating cells (primary clone) originating from a single cell can generate multiple cell types, including neurons, astrocytes, and oligodendrocytes. For subcloning, primary clones were dissociated and replated as single cells under clonal conditions in FGF-2-containing medium; a subset of cells proliferated to give rise to secondary clones. Secondary clones were also able to generate neurons, astrocytes, and oligodendrocytes. Subcloning analysis demonstrates the capacity of a cell to generate progeny similar to itself (i.e., self-renewal). These experiments demonstrate the presence of multipotent progenitor cells in adult rat spinal cord that proliferate in the presence of FGF-2 and are capable of self-renewal. $\beta-G A L$, $\beta$-Galactosidase; $L T R$, long terminal repeat; RSV, Rous sarcoma virus. clonal population. When proliferating in the presence of FGF-2, daughter cells in the primary and secondary clones appeared phase bright and had short processes (Fig. $2 C$ ), and the majority (>90\%) of cells were immunoreactive for the neuroepithelial marker protein nestin (Fig. 2D). Immunocytochemical analysis of proliferating primary and secondary clones grown in the presence of FGF-2 revealed the presence of few cells $(<1 \%)$ expressing the neuronal marker $\beta$-tubulin isotype III, NeuN (data not shown), or NF-200, the oligodendroglial marker Rip, and the astrocytic marker GFAP (Fig. $2 E-G$ ). The presence of nestin immunoreactivity and the absence of antigens characteristic of differentiated neural cells indicate that the majority of cells in the clonal culture remain undifferentiated in the presence of FGF-2. However, when grown at high density in the presence of FGF-2, an increased percentage of cells expressed neuronal and glial markers. Besides the cervical region, cells representing the three major CNS lineages were generated by clones isolated from cultures of other regions of the cord, suggesting the multipotent nature of the founder cells. Subcloning of individual primary clones gave rise to multiple secondary clones. The progeny of the secondary clones was very similar to the progeny of the parent primary clones. This finding demonstrates that a clone that originated from a single cell can be dissociated and replated under the same conditions to yield more than one copy of itself. Quantitative analysis of the percentage of cells expressing neuronal and glial antigens in a cervical clonal culture showed that $1.2 \pm 0.3 \%$ of the cells were $\beta$-tubulin immunoreactive (Fig. $3 A, B$ ), $8.9 \pm 0.4 \%$ were Rip immunoreactive (Fig. $3 A, E$ ), and $0.5 \pm 0.2 \%$ were GFAP immunoreactive (Fig. $3 A$ ). Glial and neuronal markers never colocalized within the same cell. The characteristics of clones did not change with passage number.

To determine whether we could differentiate the cloned cultured cells further, cervical clonal cultures were grown at high density in the absence of FGF-2 and treated for $6 \mathrm{~d}$ with $0.5 \%$ FBS alone or with $0.5 \mu \mathrm{M} \mathrm{RA}$ in the presence of $0.5 \%$ FBS. The relative proportion of cells expressing neuronal, astroglial, and oligodendroglial antigens was determined. Withdrawal of FGF-2 and treatment with serum promoted glial differentiation. There was a significant $(p<0.01)$ increase in the percentage of cells expressing Rip (Fig. $3 A, F$ ) or GFAP (Fig. $3 A, C$ ). There was a small but nonsignificant increase in the percentage of cells differentiating 


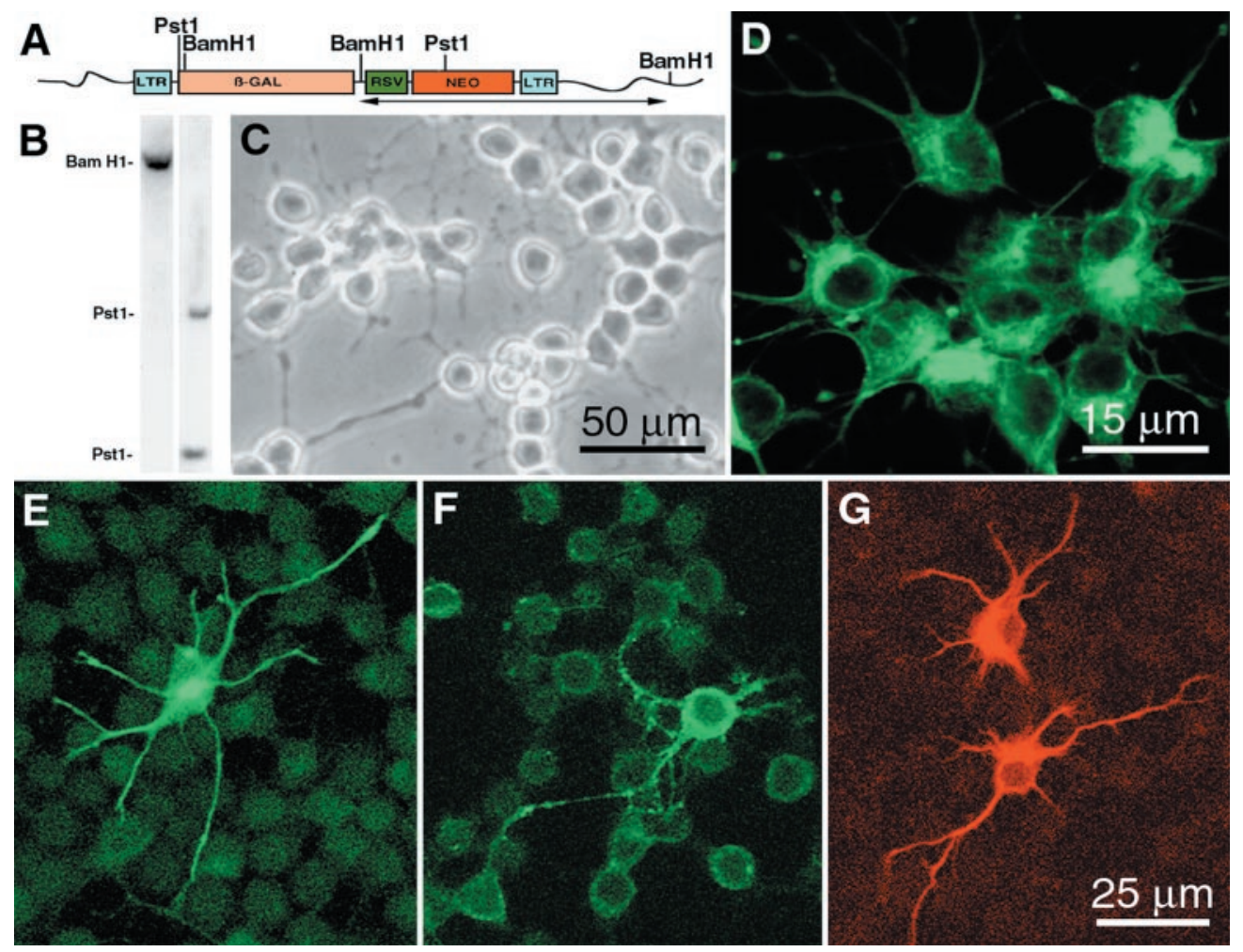

Figure 2. Expression of lineage-specific markers by a secondary clone derived from cervical spinal cord. $A$, Retroviral construct map of the vector used for cloning. The horizontal arrow beneath the retroviral construct indicates the region detected by the neomycin PCR-generated probe used to indicate the integration site of the retroviral genome. B, Southern blot analysis of BamHI- and PstI-digested genomic DNA from a cervical secondary clone. C, Phase-contrast image of proliferating daughter cells. $D-G$, Fluorescent confocal micrographs showing that the majority of cells expressed nestin $(D)$. Micrographs also show examples of cell expressing either NF-200 $(E)$, Rip $(F)$, or GFAP $(G)$. Scale bars: $C, 50 \mu \mathrm{m} ; E-G, 25 \mu \mathrm{m} ; D, 15 \mu \mathrm{m}$.

toward a neuronal lineage, as evidenced by their $\beta$-tubulin expression (Fig. 3A,C). However, RA and serum in the absence of FGF-2 significantly $(p<0.05)$ increased the percentage of cells expressing $\beta$-tubulin and GFAP in comparison with cells grown in FGF or serum alone. A total of $12.4 \%$ of the cells treated with serum and RA expressed $\beta$-tubulin isotype III and exhibited a complex neuronal morphology (Fig. 3A,D). In addition, $12.3 \%$ expressed GFAP and displayed an astrocytic phenotype (Fig. $3 A, D$ ). Varying proportions of neurons were immunopositive for neuronal markers such as NeuN, acetylcholine esterase, tyrosine hydroxylase, GABA, and calbindin (data not shown). Interestingly, combined serum and RA treatment caused a significant $(p<0.05)$ decrease or no change in the percentage of cells differentiating along an oligodendroglial lineage as compared with serum or FGF-2 treatment alone (Fig. 3A). However, cells differentiating toward oligodendroglial lineage had typical mature oligodendrocytic morphologies (Fig. 3G). These results indicate that the clonal progenitors have the characteristics of multipotent stem cells in vitro, because individual progenitors are capable of self-renewal and can generate daughter cells capable of differentiating into the three principal cell types of the CNS.

\section{Cloned and expanded adult spinal cord stem-like cells differentiate into neurons and glia after transplantation into the adult rat CNS}

Transplantation studies were conducted to determine whether cultured, clonally expanded adult spinal cord stem-like cells can generate multiple cell types in vivo and whether their fate is predefined by their region of origin or is determined by exogenous signals present in the transplanted microenvironment. Proliferating BrdUlabeled, clonally expanded cultures of stem-like cells from the cervical or thoracic spinal cord were stereotaxically transplanted into the adult spinal cord (a homotopic non-neurogenic site) and hippocampus (a heterotopic neurogenic site). Although both cervical and thoracic cells were transplanted, experiments with cervi- cal cells are shown in all figures, because transplants of cervical and thoracic clones were indistinguishable in terms of survival, distribution, and phenotypic differentiation of the transplanted cells (data not shown). Immunostaining showed that, in sister cultures of cells used for transplantation, $<1 \%$ of the cells expressed any neuronal or glial lineage markers. Immunohistochemical analysis revealed the presence of BrdU-labeled cells at 2 and 6 weeks after transplantation in both the spinal cord and hippocampus (Figs. $4 A$, $5 A$ ). In both cases, there was a broad dispersion of transplanted cells away from the injection site. BrdU-labeled cells were detected along $8-10 \mathrm{~mm}$ in the rostrocaudal axis of the adult spinal cord and in the hippocampus $2.4-3.4 \mathrm{~mm}$ along the anterior-posterior axis and 3-4 $\mathrm{mm}$ along the mediolateral axis. Six weeks after transplantation of $\sim 100,000-150,000$ cells per site, 71,542 \pm 6693 BrdUpositive cells were present in the hippocampus, and 87,450 \pm 22,408 were present in the spinal cord. The transplanted cells in all sites continued to express neo up to 7 weeks after transplantation, as shown by reverse transcriptase-nested PCR (Figs. $4 F, 5 G$ ). No neo band was detected in tissues from control spinal cord and brain, although we could readily detect the housekeeping gene glyceraldehyde-3-phosphate dehydrogenase from all samples (data not shown). $\beta$-Galactosidase immunostaining was not used to identify transplanted cells, because clones lost the expression of the LacZ gene before transplantation.

In the spinal cord, at 2 and 6 weeks after transplantation, none of the transplanted BrdU nuclei had large round morphologies or expressed the neuronal marker NeuN like endogenous spinal cord neurons. A total of three sections per rat that contained an average of $350 \pm 120 \mathrm{BrdU}$ nuclei were examined for BrdU and NeuN colocalization. A total of $\sim 8400$ nuclei were found to be NeuN negative, indicating that the expression of a neuronal phenotype is rare. Several glia-associated markers were chosen to classify the fate of BrdU-labeled cells. The presence of glial progenitors was determined by colocalization with the proteoglycan marker NG2 
A
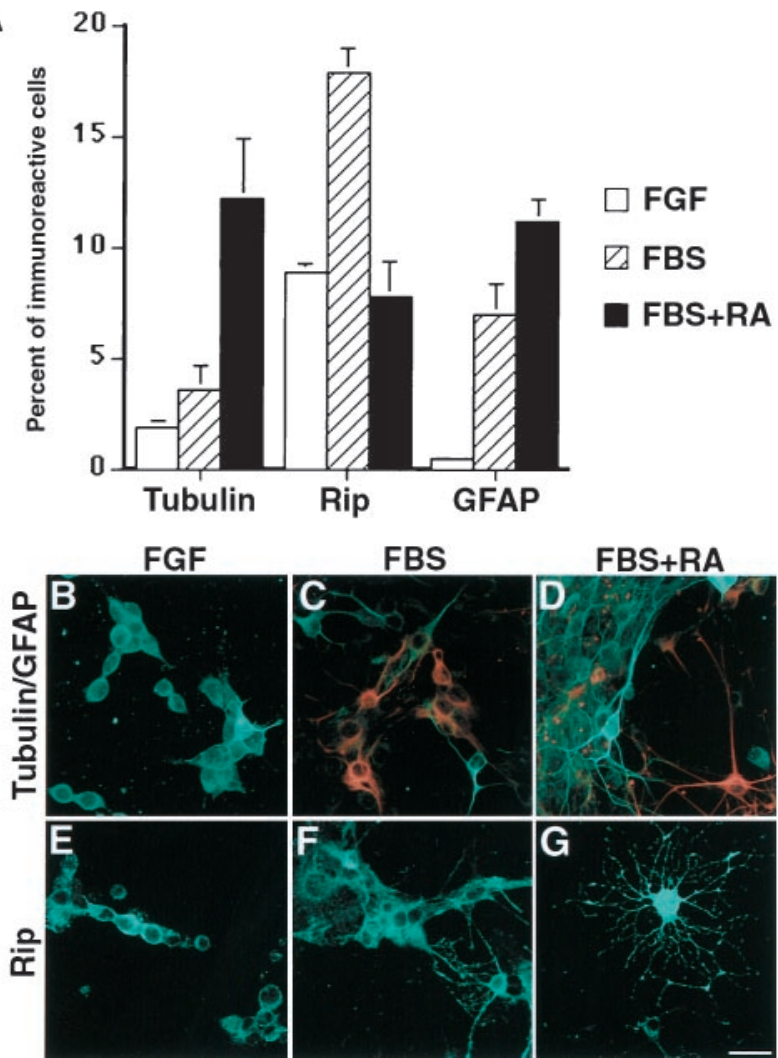

Figure 3. Distribution of neurons and glia in cervical clonal cultures. $A$, Quantitation of cells differentiating down neuronal (Tubulin) or glial (GFAP or Rip) lineages in high cell density grown in N2 + FGF $(F G F)$, $\mathrm{N} 2+0.5 \%$ serum $(F B S)$, or $\mathrm{N} 2+0.5 \%$ serum $+0.5 \mu \mathrm{M}$ retinoic acid $(F B S+R A)$ for $6 \mathrm{~d}$. Values represent the mean \pm SEM from three separate differentiation experiments. $B-G$, Representative immunofluorescent staining of $\beta$-tubulin-immunoreactive cells (green in $B-D$ ), GFAPimmunoreactive cells (red in $C, D$ ), and Rip-immunoreactive cells ( green in $E-G)$ generated in a secondary clone in response to $F G F(B, E), F B S(C$, $F)$, or $F B S+R A(D, G)$. Scale bar: $B-G, 25 \mu \mathrm{m}$.

(Stallcup and Beasley, 1987). Astrocytes were identified by staining for GFAP-positive cells. Expression of Rip or APC tumor suppressor gene immunoreactivity in the absence of GFAP expression was used to identify mature oligodendrocytes (Friedman et al., 1989; Bhat et al., 1996). NG2 was expressed by $14.3 \pm 1.3 \%$ of BrdUlabeled transplanted cells (Fig. 4B). Cells expressing NG2 had unipolar, bipolar, or multipolar morphologies. In the white matter of the spinal cord, the percentage $(22.0 \pm 3.8 \%)$ of BrdU-labeled cells that colabeled with NG2 was higher than the percentage $(9.4 \pm 1.6 \%)$ in the gray matter. Some BrdU-positive cells had small rounded somas with large nuclei surrounded by a rim of cytoplasm that stained with Rip (Fig. $4 D)$ or APC $(3.4 \pm 1.1 \%)$ but did not colabel with GFAP (Fig. $4 C$ ), indicating that some of the transplanted cells differentiated into oligodendrocytes. A small population of transplanted cells also differentiated into astrocytes $(6.0 \pm 0.4 \%$; Fig. $4 E)$. A recent study from this lab demonstrated the presence of progenitor cells within the gray and white matter of the adult spinal cord as well as in the central canal. A percentage of these mitotic cells appears to be a source of newborn astrocytes $(3.9 \pm 0.5 \%)$ and oligodendrocytes $(5.4 \pm 1.0 \%)$ but not neurons within the intact cord (Horner et al., 2000). Thus, transplanted cells behaved similarly to endogenous proliferating cells, in terms of the percentage of cells differentiating and the phenotypes they generate, i.e., glial, but not neuronal, cell types.

Interestingly, in the hippocampus, transplanted cells that migrated into neuronal layers of the dentate gyrus expressed the neuronal marker NeuN (Fig. $5 H-J$ ). At 2 weeks after transplantation, the double-labeled cells were mainly located in the subgranular zone or within the first layer of the granular cell layer (GCL;

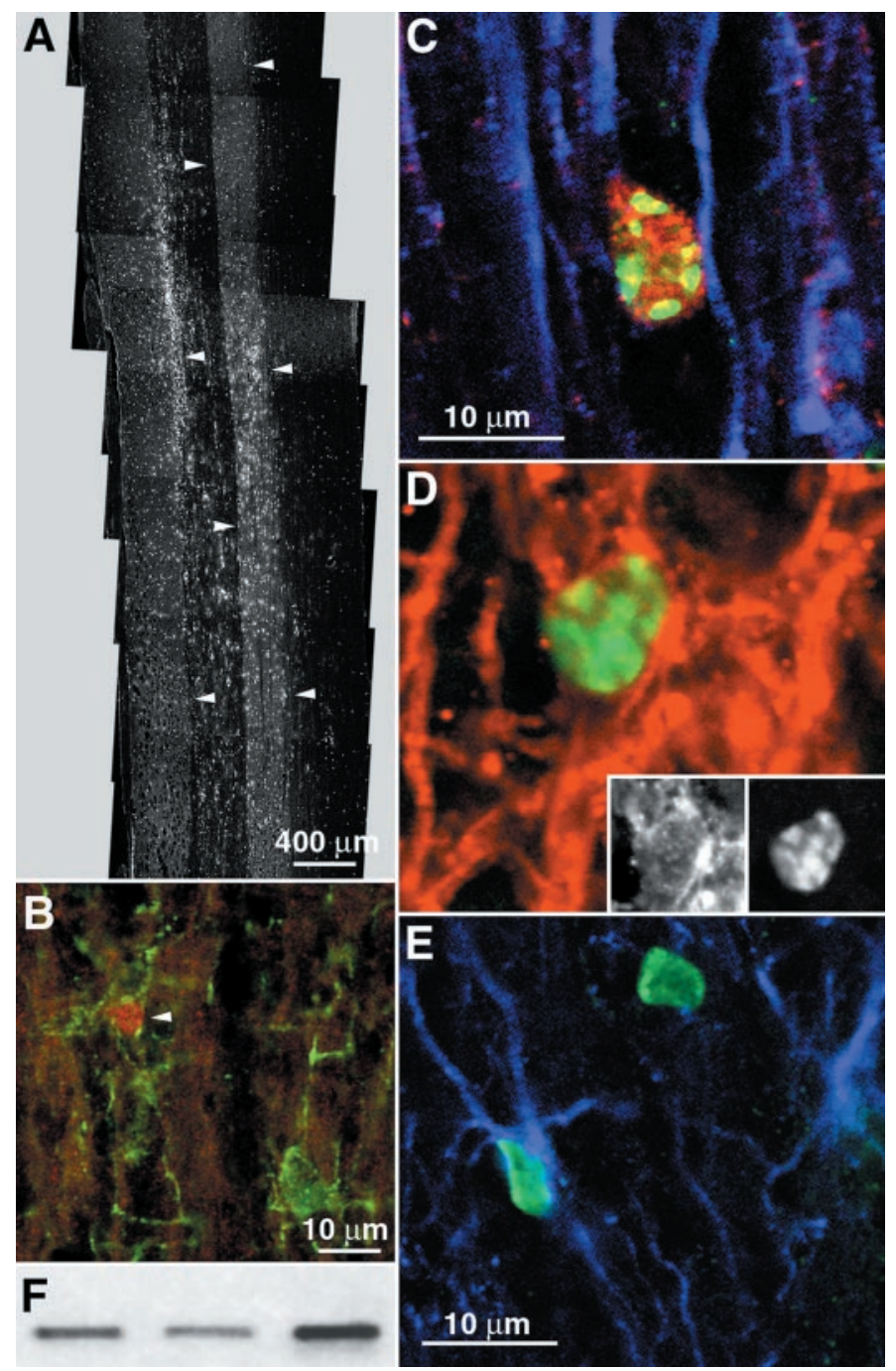

Figure 4. Distribution and differentiation of clonally expanded adult spinal cord stem-like cells (cervical clone) 6 weeks after transplantation into the adult rat spinal cord. $A$. Horizontal section of the thoracic spinal cord showing the dispersion of transplanted cells. Arrowheads outline the borders of gray matter. $B$, Glial progenitor phenotype of transplantderived cells. Arrowhead indicates a NG2 (green) and BrdU (red)immunoreactive transplanted cell in the white matter of the spinal cord. $C, D$, Oligodendroglial phenotype of transplant-derived cells at 6 weeks. $C$, BrdU-immunoreactive transplanted cell expressing APC (red) and not GFAP (blue). D, Merged images of a transplanted cell expressing Rip (red) and BrdU (green). Insets, Single-channel images of the above cell expressing Rip in the cytoplasm and BrdU in the nucleus. $E$, Colocalization of BrdU-labeled transplanted cells ( green) with GFAP (blue) immunoreactivity. $F$, Expression of the neomycin gene in spinal cord transplant sites of three animals as detected by reverse transcriptase-nested PCR. Scale bars: $A, 400 \mu \mathrm{m} ; B, 10 \mu \mathrm{m} ; C, D, 10 \mu \mathrm{m} ; E, 10 \mu \mathrm{m}$.

data not shown). However, at 6 weeks after transplantation, many NeuN-expressing, BrdU-labeled cells were seen spanning the depth of the GCL (Fig. 5H). Similar results were obtained when hippocampus-derived progenitor cells were transplanted homotopically at this site (Gage et al., 1995; Suhonen et al., 1996). Some BrdU-labeled cells had morphologies characteristic of hippocampal granule neurons, with large rounded nuclei, an ovoid cell body that displayed polarized dendritic processes, and calbindin- $\mathrm{D}_{28 \mathrm{k}}$ expression (Fig. 5M,P). There were differences in the sizes and shapes of the nuclei of cells that differentiated into granular neurons (Fig. $5 M$, boxed area, $N-R$ ) and of cells that did not differentiate (Fig. 5M, arrowheads). Quantitative analysis showed that, within the dentate gyrus, $47.5 \pm 3.7 \%$ of transplanted cells that integrated in the GCL expressed NeuN (Fig. $5 H-J$ ), $43.7 \pm 3.7 \%$ expressed calbindin, and $2.8 \pm 0.6 \%$ expressed GFAP (Fig. 5E). 

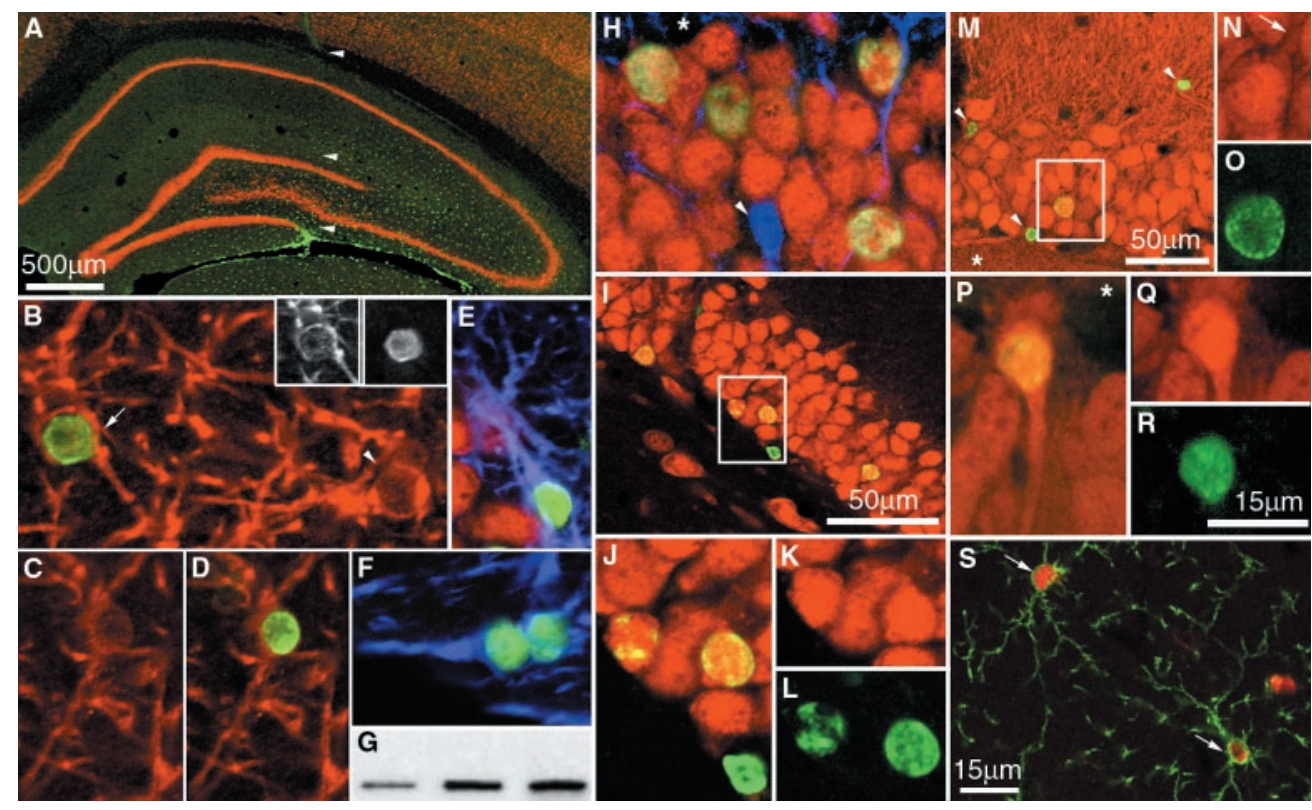

Figure 5. Distribution and differentiation of clonally expanded, adult spinal cord stem-like cells (cervical clone) 6 weeks after transplantation in the adult rat hippocampus. $A$, Coronal view of the adult rat hippocampus shows the broad dispersion of transplanted BrdU-immunoreactive cells (green). Arrowheads indicate the needle tract. B, BrdU-immunoreactive cell (green) colocalizes with Rip immunoreactivity (red) in the molecular layer of the hippocampus (cell indicated by arrow). Insets, The shape of the BrdU-labeled nucleus (right) fits the shape of the nucleus of the Rip-expressing cell (left). The arrowhead in $B$ indicates a Rip-expressing endogenous oligodendrocyte. $C, D$, Merged images of a cell expressing Rip $(C)$ colocalized with BrdU $(D)$ shown. $E, F$, BrdU-immunoreactive cells ( green) expressing GFAP (blue) in the ventral leaf of the GCL $(E)$ and lining the cerebral ventricle $(F)$ are shown. $G$, Expression of the neomycin gene in hippocampal transplant sites of three animals is shown. $H-J$, Yellow indicates transplanted cells within the GCL double-labeled for NeuN (red) and BrdU (green). The arrowhead in $H$ indicates an endogenous astrocyte expressing GFAP. Asterisks in $H$, $M$, and $P$ indicate the location of the hilus. The boxed area in $I$ is shown at higher magnification in $J$. $K, L$, Merged images of cells $(J)$ immunostained for NeuN $(K)$ and $\operatorname{BrdU}(L)$ are shown. $M, P$, BrdU-immunoreactive cells ( green) express calbindin (red) in the GCL. Arrowheads in $M$ indicate transplanted cells that did not differentiate. The arrow in $N$ indicates the apical process of a transplanted cell extending toward the molecular layer (boxed area in $M$ ). $N$, $O, Q, R$, Unmerged images of transplanted cells $(M, P)$ immunostained for calbindin $(N, Q)$ and $\operatorname{BrdU}(O, R)$ in the dorsal and ventral leaves of the GCL, respectively, are shown. $S$, BrdU-immunoreactive cells (red) colocalize with NG2 immunoreactivity ( $g r e e n$ ) in the molecular layer of the hippocampus (cells indicated by arrows). Scale bars: $A, 500 \mu \mathrm{m} ; M, I, 50 \mu \mathrm{m}$; (shown in $R$ ) $B-F, H, J-L, N-R, 15 \mu \mathrm{m} ; S, 15 \mu \mathrm{m}$.

NG2 was also expressed by $21.5 \% \pm 5.7 \%$ of BrdU-labeled cells located in the GCL and SGZ of the dentate gyrus. In other non-neurogenic regions of the hippocampus, $33.8 \pm 4.7 \%$ of BrdUlabeled cells colabeled with the glial progenitor marker NG2 (Fig. $5 S)$. A small population of all grafted cells exhibited morphologies similar to endogenous oligodendrocytes and expressed the oligodendroglial marker Rip $(2.8 \pm 0.2 \%$; Fig. $5 B-D)$ or had astrocytic phenotypes $(3.5 \pm 0.8 \%$; Fig. $5 F)$ but did not express NeuN. The majority of the cells remained undifferentiated and did not express any mature neuronal or glial markers. The quantified results of the grafted cervical clone progenitor cell phenotypes are presented in Table 1.

Colocalization of synaptophysin-immunoreactive synaptic elements and BrdU-labeled newborn granule cells was used to explore the level of differentiation and integration of grafted cells. Calbindin-immunoreactive cells were rarely found associated with synaptic elements at 2 weeks after transplantation. By 6 weeks after transplantation, many cells had synaptophysin-immunoreactive elements associated with the cell surface (Fig. 6A,B). Post hoc analysis of confocal $\mathrm{Z}$ stacks demonstrated that synaptophysinimmunoreactive elements could be seen making contact with BrdU-labeled cells in all three dimensions (Fig. 6A, XY, XZ, YZ). In addition to receiving synaptic contacts, BrdU-labeled cells only expressed calbindin when located within the granule cell layer. In the hippocampus, calbindin is specifically located in dentate granule neurons and superficial CA1 pyramidal neurons and a subset of GABAergic neurons (Baimbridge and Miller, 1982; Celio, 1990). Calbindin-labeled neurons are restricted to the dentate GCL. Few cells were immunoreactive within the adjacent CA1 region; however, numerous calbindin-immunoreactive processes are seen that are presumably from dentate granule cells (Fig. $6 C-E$ ).

There was no indication of continuous cell proliferation of transplanted cells, as evidenced by the lack of detectable colabeling of
Table 1. Phenotypic distribution of cloned spinal cord progenitor cell transplants

\begin{tabular}{lclc} 
& & \multicolumn{2}{l}{ Hippocampus } \\
\cline { 3 - 4 } Phenotype & Spinal cord $(\%)$ & GCL $(\%)$ & MCL+CA1+CA3 $(\%)$ \\
\hline NeuN & 0 & 48 & 3 \\
Calb & ND & 44 & 0 \\
NG2 & 14 & 22 & 26 \\
Rip & 3 & 3 & 3 \\
GFAP & 6 & 3 & 3
\end{tabular}

Relative expression of neuronal and glial markers by transplanted adult spinal cord progenitor cells in the spinal cord and hippocampal formation at 6 weeks after transplantation. Sections were triple-labeled with BrdU, neuronal markers [calbindin (Calb) and NeuN], a glial progenitor marker (NG2), an astrocytic maker (GFAP), and an oligodendrocytic marker (Rip) and analyzed by confocal microscopy. MCL, Molecular cell layer; ND, not determined.

BrdU and the proliferation marker Ki-67 (Schluter et al., 1993) between 2 and 6 weeks after transplantation (Fig. 7). However, these data do not exclude the possibility that the transplanted cells continued to proliferate after transplantation and that some cells may have thereby diluted the BrdU signal below a detectable level. To confirm that BrdU-labeled cells that exhibited characteristic neuronal or glial phenotypes in vivo after transplantation were transplant-derived and not caused by the transfer of BrdU from the transplanted living or dead cells to endogenous host cells, control transplants of BrdU-labeled fibroblasts and of dead BrdUlabeled progenitor cells were performed (Fig. 8). Transplantation of 150,000 BrdU-labeled, clonally expanded adult spinal cord stemlike cells that were freeze-thawed before transplantation $(0 \%$ viability as determined by trypan blue exclusion) showed a few BrdU- 

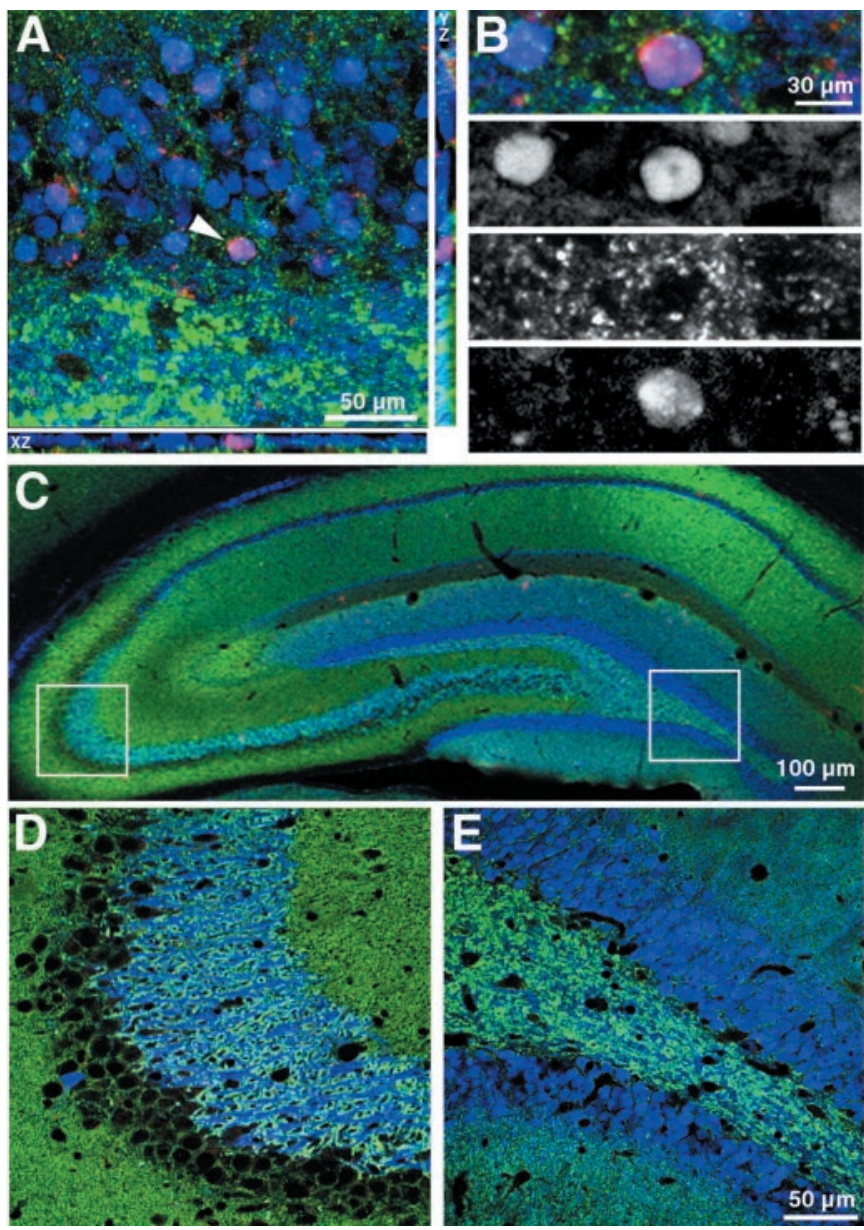

Figure 6. Association of clonally expanded, adult spinal cord stem-like cells (cervical clone) 6 weeks after transplantation in the adult rat hippocampus with the synaptic marker synaptophysin. $A$, Coronal view of the granule cell layer showing a BrdU (red) and calbindin (blue)-colabeled nucleus that is closely associated with synaptophysin (green)-immunoreactive synaptic processes. Computer-generated $\mathrm{XZ}$ and $\mathrm{YZ}$ views of the of the Z-series stack are positioned below and to the right, respectively. Views in the XZ and YZ plane are taken from the point indicated by the arrowhead. Note the intimate association of synaptophysin-immunoreactive profiles with the BrdU-labeled cell membrane in all three planes of view. $B$, Confocal image of the BrdUlabeled cell from $A$ separated into individual blue, green, and red channels. $C-E$, Calbindin labeling in the dentate gyrus and CA fields of the hippocampus. The left (CA3) and right (dentate) boxed areas in $C$ are shown at higher magnification in $D$ and $E$, respectively. Note that calbindin is rarely expressed by neurons in the CA3 region $(D)$, whereas it is ubiquitously expressed by neurons in the dentate $(E)$. Scale bars: $C, 100 \mu \mathrm{m} ; A, 50 \mu \mathrm{m} ; D, E, 50 \mu \mathrm{m} ; B$, $30 \mu \mathrm{m}$.

labeled nuclei of dead cells $(<0.5 \%$ of transplanted cells), surrounded by reactive astrocytes, clustering around the injection site only. None of the BrdU-labeled dead cell nuclei detected within the GCL or other regions of the hippocampus colocalized with NeuN, GFAP (Fig. $8 A, B$ ), or Rip (data not shown). Thus, endogenous cells do not take up BrdU that might be leaking from damaged or dead cells. Furthermore, BrdU-labeled fibroblasts survived after transplantation into the adult rat hippocampus, but none of the BrdU-labeled cells that were detected colocalized with any neuronal or glial marker used (Fig. $8 C, D$ ). In these control experiments we found no evidence that there is transfer of BrdU from dead or living cells to host cells.

\section{DISCUSSION}

Spinal cord-derived neural precursor cells exhibit varying properties depending on their source and culture conditions. Neuroepithelial stem cells from the embryonic rat spinal cord require FGF and chicken embryo extract to proliferate and maintain an undifferentiated phenotype in culture (Kalyani et al., 1997; Mujtaba et

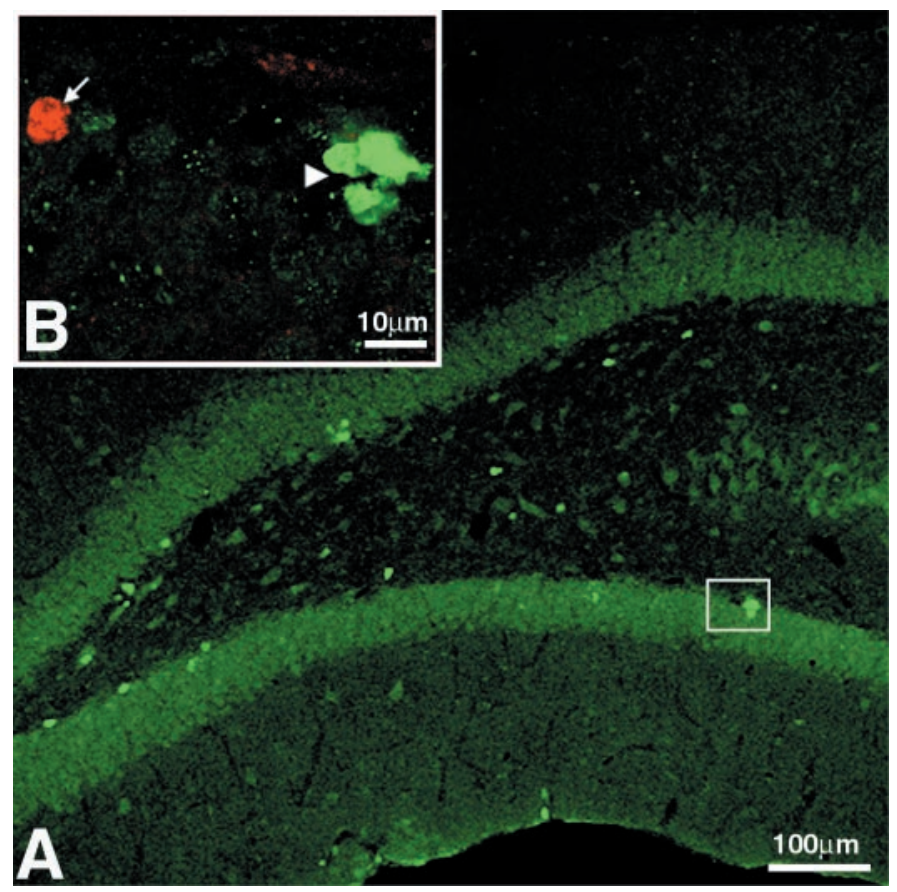

Figure 7. Proliferation of clonally expanded, adult spinal cord stem-like cells after transplantation. Immunofluorescence of BrdU (red) is combined with labeling for the proliferation marker Ki-67 (green). A, Coronal view of the adult rat hippocampus showing the presence of some proliferating cells in the subgranular zone, GCL, and hilus. The boxed area is shown at a higher magnification in $B$. B, A cluster of proliferating cells in the subgranular zone (arrowhead) adjacent to a BrdU-labeled cell (arrow) in the GCL.

al., 1998). Neural precursor cells were isolated from the postnatal day 15 (P15) to P16 (Kehl et al., 1997) and adult rat spinal cord (Shihabuddin et al., 1997) using conditioned medium from fetal astrocytes and FGF-2, respectively. Although in the first study the isolated neural precursors gave rise to neurons, the latter cultures contained cells expressing neuronal, astrocytic, and oligodendrocytic antigens. However, these studies did not determine whether these neural precursors are unipotent or multipotent cells and whether they can self-renew. Subcloning experiments of FGF-2responsive progenitors showed that some individual cells from primary clones generated secondary clones that retained multipotentiality. Using retroviral marking we also demonstrated that clones originating from a single cell could differentiate and give rise to neurons, astrocytes, and oligodendrocytes. Collectively, the data show that FGF-responsive progenitors possess the two fundamental properties that define stem cells: self-renewal and multipotency.

The majority of FGF-2-responsive spinal cord progenitors were undifferentiated and expressed nestin. Although some cells in a clone were immunoreactive for the neuronal marker $\beta$-tubulin isotype III, the astroglial marker GFAP, and the oligodendroglial marker Rip, they did not display mature morphological phenotypes. Removal of FGF-2 and combined treatment of the cultures with serum and RA increased the percentage of cells that display more mature neuronal and glial morphologies and express specific markers. These results suggest that treatment of cells with a differentiating agent was necessary to promote more mature differentiation toward both neuronal and glial lineages.

Few in vivo studies have explored the developmental capacity and multipotency of adult CNS-derived stem cell progeny from neurogenic areas like the dentate gyrus and SVZ, and little is known about the behavior or fate of non-neurogenic site-derived cells after transplantation. Our study, similar to a previous study (Suhonen et al., 1996), demonstrates that in vitro-expanded, FGF2-responsive adult spinal cord stem cells can give rise to both neurons and glia in vivo after transplantation. In contrast, trans- 
Figure 8. Distribution and differentiation of control transplants at 6 weeks after transplantation in the adult rat hippocampus. Immunofluorescence for BrdU (green) is combined with labeling for NeuN (red) and GFAP (blue). A, Freeze-thawed, BrdUlabeled, clonally expanded adult spinal cord stem-like cells show minimal dispersion from the injection tract (indicated by arrowheads). Intense GFAP staining is observed surrounding the transplant. The boxed area is shown at higher magnification in $B . B$ Freeze-thawed, BrdU-labeled nuclei in the GCL do not express NeuN (arrowhead) or GFAP (arrows). $C$, BrdU-labeled fibroblast transplant into the hippocampus is shown. Minimal dispersion of the transplanted fibroblasts from the injection tract is seen. Arrowheads indicate the needle tract. $D$, BrdU labeled cells in the GCL (arrowhead) do not colocalize with NeuN or with GFAP ( $a r$ rows). Scale bars: $A, C, 100 \mu \mathrm{m} ; B, D, 25 \mu \mathrm{m}$.
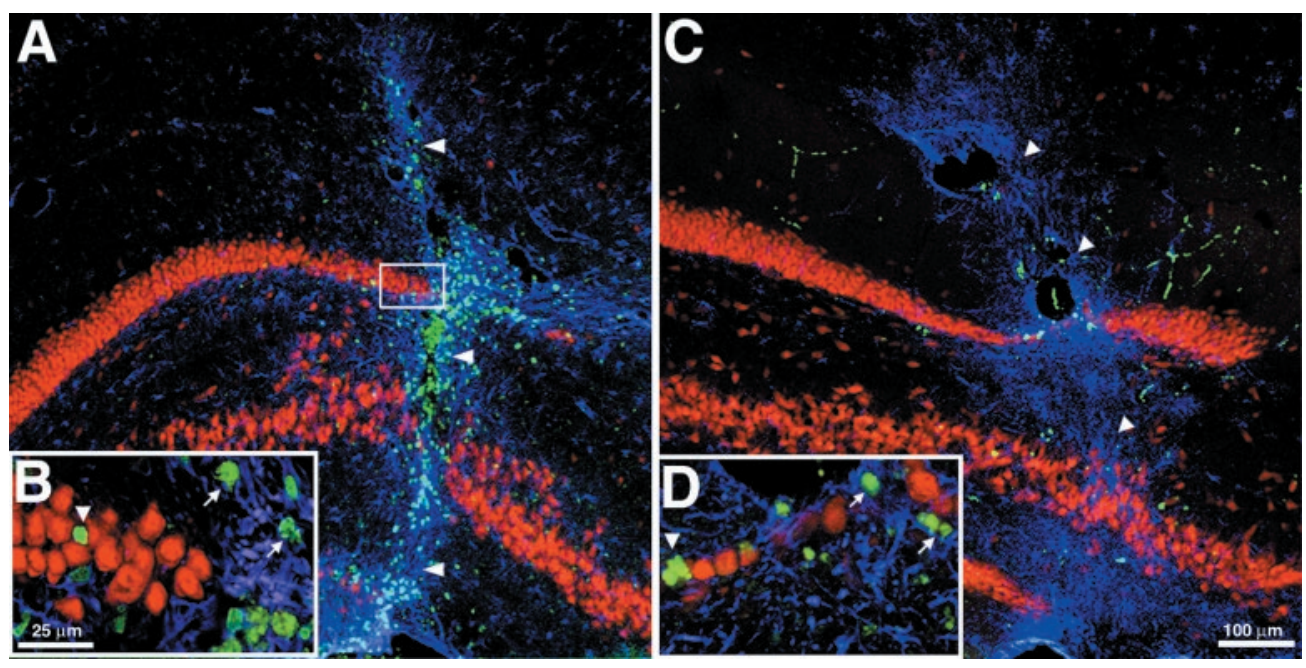

plantation of EGF-responsive neurospheres derived from embryonic striata and ventral mesencephalon into the developing forebrain or adult spinal cord showed poor survival (Svendsen et al., 1996) and generated only glial cells and no neurons (Hammang et al., 1997; Winkler et al., 1998).

The present study differs from a previous transplantation study (Suhonen et al., 1996) in that the cells used here were a clonally expanded population from a non-neurogenic site rather than a bulk population of cells derived from the hippocampus, a site that exhibited ongoing neurogenesis throughout adulthood (Kaplan and Hinds, 1977; Kuhn et al., 1996; Cameron et al., 1998). Interestingly, clonally expanded spinal cord cells behave like endogenous proliferating spinal cord cells when transplanted in the adult spinal cord (Horner et al., 2000) by differentiating into glia only. In contrast, in the adult hippocampus, the same cloned stem cells from the adult spinal cord are induced by local signals to express mature neuronal morphologies and antigenic markers similar to resident hippocampal granular neurons in the GCL. Specifically, grafted cells express calbindin that is distinct for the GCL and begin receiving synaptic contacts at 6 weeks after transplantation. In non-neurogenic regions of the hippocampus, the same transplanted cells differentiated into glial cells only. These findings suggest that the fate of adult spinal cord-derived stem cells can be determined in vivo by external signals rather than predetermined by an internal program dictated by their region of origin. A broader implication of our results is that the absence of neurogenesis in the adult rat spinal cord is not caused by the inability of stem-like cells to generate neurons but rather by the lack of local cues essential for the neuronal differentiation of progenitor cells. In agreement with the present findings, Takahashi et al. (1998) have shown that cloned adult hippocampal progenitors transplanted into the developing eye adopt morphologies similar to those of neuronal and astroglial cells of the retina. However these cells were grafted into the developing retina and did not ultimately express mature neuronal or glial markers, suggesting that cellular differentiation was incomplete. In view of the present findings, this study suggests that the developing environment may not provide proper instruction for adult-derived stem cells as compared with that of the mature CNS.

One caveat of these findings is that, although the present study demonstrated that the progeny of clonal cultures of stem-like cells could give rise to cells of multiple lineages, this study does not prove that the differentiated cells arise from multipotent stem cells. FGF-2 appears to be a mitogen for both unipotent and multipotent progenitors (Murphy et al., 1990; Ray et al., 1993; Kilpatrick and Bartlett, 1995; Palmer et al., 1995, 1997; Gritti et al., 1996; Kalyani et al., 1997; Mujtaba et al., 1998). The clonal culture of progenitors from the adult spinal cord maintained in FGF-2 may contain a mixture of multipotent and lineage-restricted cells at various stages of development, with a small fraction retaining stem cell properties. Our data show that clonal cultures of adult spinal cord progenitors containing cells of various lineages differentiate into both neurons and glia. Thus, it is possible that cells that differentiate into mature cells in vivo may be a specific subset of partially differentiated cells, whereas the most immature cells may either not survive or remain quiescent after transplantation. However, a noteworthy finding of this study is that stem-like progenitor cells isolated from the adult spinal cord, a non-neurogenic zone, can give rise to differentiated cells with characteristics of granular neurons of the hippocampus after transplantation. Furthermore, although the spinal cord and brain morphogeneses diverge very early during development, a common stem cell that can give rise to the principal cell types of the CNS may exist in both. The stem cells from distinct parts of the neuroepithelium may not be restricted to a local fate, and thus their fate may be determined by noncell autonomous signals of their local environment. In an extreme example of this, a recent study demonstrated that genetically labeled neural stem cells transplanted into irradiated hosts gave rise to a variety of blood cell types (Bjornson et al., 1999), suggesting that the differentiation potential of neural stem cells is much broader than thought previously. An alternative to the theory of a common stem cell existing in both the spinal cord and brain is the possibility of cellular reprogramming or dedifferentiating as a result of culturing cells before reintroducing them into the adult brain. For example, persistent exposure of cultured stem cells to mitogens may alter their developmental fate and broaden their differentiation potential after transplantation (Palmer et al., 1999).

The present study demonstrates that expanded, clonal stem cell-derived progenitors from an adult non-neurogenic zone (spinal cord) exhibit remarkable capacity for integration and site-specific differentiation in the adult spinal cord and hippocampal region of the brain. Although transplantation studies using bulk populations of progenitors have shown site-specific neuronal differentiation in neurogenic sites of the adult brain, to the best of our knowledge, this is the first report demonstrating that in vitro-generated, clonal multipotent cells from a non-neurogenic site of the adult nervous system show remarkable plasticity and an ability to respond to epigenetic signals in vivo by generating region-specific neurons. Although targeted recruitment of endogenous stem cells in the adult CNS remains to be shown, there are data suggesting that endogenous cells are amenable to modulation by intraventricular infusion of growth factors (Craig et al., 1996; Kuhn et al., 1997). Further identification of molecules that direct differentiation of adult stem cell progeny along specific lineages may enable the induction of neurogenesis in the adult spinal cord.

\section{REFERENCES}

Adrian Jr EK, Walker BE (1962) Incorporation of thymidine- ${ }^{3} \mathrm{H}$ by cells in normal and injured mouse spinal cord. J Neuropathol Exp Neurol 21:597-609.

Altman J, Bayer SA (1984) The development of the rat spinal cord. Adv Anat Embryol Cell Biol 85:1-164. 
Baimbridge KG, Miller JJ (1982) Immunohistochemical localization of calcium-binding protein in the cerebellum, hippocampal formation and olfactory bulb of the rat. Brain Res 245:223-229.

Bayer SA, Yakel SW, Puri PS (1982) Neurons in the rat dentate gyrus granular layer substantially increase during juvenile and adult life. Science 216:890-892.

Bhat RV, Axt KJ, Fosnaugh JS, Smith KJ, Johnson KA, Hill DE, Kinzler KW, Baraban JM (1996) Expression of the APC tumor suppressor protein in oligodendroglia. Glia 17:169-174.

Bjornson CR, Rietze RL, Reynolds BA, Magli MC, Vescovi AL (1999) Turning brain into blood: a hematopoietic fate adopted by adult neural stem cells in vivo. Science 283:534-537.

Brustle O, Spiro AC, Karram K, Choudhary K, Okabe S, McKay RD (1997) In vitro-generated neural precursors participate in mammalian brain development. Proc Natl Acad Sci USA 94:14809-14814.

Brustle O, Choudhary K, Karram K, Huttner A, Murray K, Dubois-Dalcq M, McKay RDG (1998) Chimeric brains generated by intraventricular transplantation of fetal human brain cells into embryonic rats. Nat Biotechnol 16:1040-1044.

Cameron HA, Hazel TG, McKay RD (1998) Regulation of neurogenesis by growth factors and neurotransmitters. J Neurobiol 36:287-306.

Celio MR (1990) Calbindin D-28k and parvalbumin in the rat nervous system. Neuroscience 35:375-475.

Ciccolini F, Svendsen CN (1998) Fibroblast growth factor 2 (FGF-2) promotes acquisition of epidermal growth factor (EGF) responsiveness in mouse striatal precursor cells: identification of neural precursors responding to both EGF and FGF-2. J Neurosci 18:7869-7880.

Craig CG, Tropepe V, Morshead CM, Reynolds BA, Weiss S, van der Kooy $\mathrm{D}$ (1996) In vivo growth factor expansion of endogenous subependymal neural precursor cell populations in the adult mouse brain. J Neurosci 16:2649-2658.

Flax JD, Aurora S, Yang C, Simonin C, Wills AM, Billinghurst LL, Jendoubi M, Sidman RL, Wolfe JH, Kim SU, Snyder EY (1998) Engraftable human neural stem cells respond to developmental cues, replace neurons, and express foreign genes. Nat Biotechnol 16:1033-1039.

Friedman B, Hockfield S, Black JA, Woodruff KA, Waxman SG (1989) In situ demonstration of mature oligodendrocytes and their processes: an immunocytochemical study with a new monoclonal antibody, rip. Glia 2:380-390.

Gage FH, Coates PW, Palmer TD, Kuhn HG, Fisher LJ, Suhonen JO, Peterson DA, Suhr ST, Ray J (1995) Survival and differentiation of adult neuronal progenitor cells transplanted to the adult brain. Proc Natl Acad Sci USA 92:11879-11883.

Gritti A, Parati EA, Cova L, Frolichsthal P, Galli R, Wanke E, Faravelli L, Morassutti DJ, Roisen F, Nickel DD, Vescovi AL (1996) Multipotential stem cells from the adult mouse brain proliferate and self-renew in response to basic fibroblast growth factor. J Neurosci 16:1091-1100.

Gritti A, Frolichsthal-Schoeller P, Galli R, Parati EA, Cova L, Pagano SF, Bjornson CR, Vescovi AL (1999) Epidermal and fibroblast growth factors behave as mitogenic regulators for a single multipotent stem cell-like population from the subventricular region of the adult mouse forebrain. J Neurosci 19:3287-3297.

Hall PA, Watt FM (1989) Stem cells: the generation and renewal of cellular diversity. Development 106:619-633.

Hammang JP, Archer DR, Duncan ID (1997) Myelination following transplantation of EGF-responsive neural stem cells into a myelindeficient environment. Exp Neurol 147:84-95.

Horner PJ, Power AE, Kempermann G, Kuhn HG, Palmer TD, Winkler J, Thal LJ, Gage FH (2000) Proliferation and differentiation of progenitor cells throughout the intact adult rat spinal cord. J Neurosci 20:2218-2228.

Johansson CB, Momma S, Clarke DL, Risling M, Lendahl U, Frisen J (1999) Identification of a neural stem cell in the adult mammalian central nervous system. Cell 96:25-34.

Kalyani A, Hobson K, Rao MS (1997) Neuroepithelial stem cells from the embryonic spinal cord: isolation, characterization, and clonal analysis. Dev Biol 186:202-223.

Kaplan MS, Hinds JW (1977) Neurogenesis in the adult rat: electron microscopy analysis of light radioautographs. Science 197:1092-1094.

Kaplan MS, Hinds JW (1980) Gliogenesis of astrocytes and oligodendrocytes in the neocortical grey and white matter of the adult. J Comp Neurol 193:711-727.

Kehl LJ, Fairbanks CA, Laughlin TM, Wilcox GL (1997) Neurogenesis in postnatal rat spinal cord: a study in primary culture. Science 276:586-589. Kilpatrick TJ, Bartlett PF (1995) Cloned multipotential precursors from the mouse cerebrum require FGF-2, whereas glial restricted precursors are stimulated with either FGF-2 or EGF. J Neurosci 15:3653-3661.

Kuhn HG, Dickinson-Anson H, Gage FH (1996) Neurogenesis in the dentate gyrus of the adult rat: age-related decrease of neuronal progenitor proliferation. J Neurosci 16:2027-2033.

Kuhn HG, Winkler J, Kempermann G, Thal LJ, Gage FH (1997) Epidermal growth factor and fibroblast growth factor-2 have different effects on neural progenitors in the adult rat brain. J Neurosci 17:5820-5829.

Lois C, Alvarez-Buylla A (1993) Proliferating subventricular zone cells in the adult mammalian forebrain can differentiate into neurons and glia. Proc Natl Acad Sci USA 90:2074-2077.

Lois C, Alvarez-Buylla A (1994) Long-distance neuronal migration in the adult mammalian brain. Science 264:1145-1148.

Luskin MB (1993) Restricted proliferation and migration of postnatally generated neurons derived from the forebrain subventricular zone. Neuron 11:173-189.

Miller AD, Rosman GJ (1989) Improved retroviral vectors for gene transfer and expression. Biotechniques 7:980-990.

Morshead CM, Reynolds BA, Craig CG, McBurney MW, Staines WA, Morassutti D, Weiss S, van der Kooy D (1994) Neural stem cells in the adult mammalian forebrain: a relatively quiescent subpopulation of subependymal cells. Neuron 13:1071-1082.

Mujtaba T, Mayer-Proschel M, Rao MS (1998) A common progenitor for the CNS and PNS. Dev Biol 200:1-15.

Murphy M, Drago J, Bartlett PF (1990) Fibroblast growth factor stimulates the proliferation and differentiation of neural precursor cells in vitro. J Neurosci Res 25:463-475.

Nornes HO, Das GD (1974) Temporal pattern of neurogenesis in spinal cord of rat. I. An autoradiographic study-time and sites of origin and migration and settling patterns of neuroblasts. Brain Res 73:121-138.

Palmer TD, Ray J, Gage FH (1995) FGF-2-responsive neuronal progenitors reside in proliferative and quiescent regions of the adult rodent brain. Mol Cell Neurosci 6:474-486.

Palmer TD, Takahashi J, Gage FH (1997) The adult rat hippocampus contains primordial neural stem cells. Mol Cell Neurosci 8:389-404.

Palmer TD, Markakis EA, Willhoite AR, Safar F, Gage FH (1999) Fibroblast growth factor-2 activates a latent neurogenic program in neural stem cells from diverse regions of the adult CNS. J Neurosci 19:84878497.

Rakic P (1985) Limits of neurogenesis in primates. Science 227:10541056.

Ray J, Peterson DA, Schinstine M, Gage FH (1993) Proliferation, differentiation, and long-term culture of primary hippocampal neurons. Proc Natl Acad Sci USA 90:3602-3606.

Schluter C, Duchrow M, Wohlenberg C, Becker MH, Key G, Flad HD, Gerdes J (1993) The cell proliferation-associated antigen of antibody Ki-67: a very large, ubiquitous nuclear protein with numerous repeated elements, representing a new kind of cell cycle-maintaining proteins. J Cell Biol 123:513-522.

Shihabuddin LS, Ray J, Gage FH (1997) FGF-2 is sufficient to isolate progenitors found in the adult mammalian spinal cord. Exp Neurol 148:577-586.

Stallcup WB, Beasley L (1987) Bipotential glial precursor cells of the optic nerve express the NG2 proteoglycan. J Neurosci 7:2737-2744.

Suhonen JO, Peterson DA, Ray J, Gage FH (1996) Differentiation of adult hippocampus-derived progenitors into olfactory neurons in vivo. Nature 383:624-627.

Svendsen CN, Clarke DJ, Rosser AE, Dunnett SB (1996) Survival and differentiation of rat and human epidermal growth factor-responsive precursor cells following grafting into the lesioned adult central nervous system. Exp Neurol 137:376-388.

Takahashi M, Palmer TD, Takahashi J, Gage FH (1998) Widespread integration and survival of adult-derived neural progenitor cells in the developing optic retina. Mol Cell Neurosci 12:340-348.

Temple S, Alvarez-Buylla A (1999) Stem cells in the adult mammalian central nervous system. Curr Opin Neurobiol 9:135-141.

Weiss S, Dunne C, Hewson J, Wohl C, Wheatley M, Peterson AC, Reynolds BA (1996) Multipotent CNS stem cells are present in the adult mammalian spinal cord and ventricular neuroaxis. J Neurosci 16:7599-7609. Winkler C, Fricker RA, Gates MA, Olsson M, Hammang JP, Carpenter MK, Bjorklund A (1998) Incorporation and glial differentiation of mouse EGF-responsive neural progenitor cells after transplantation into the embryonic rat brain. Mol Cell Neurosci 11:99-116. 